\title{
Línguas de ritmo silábico
}

\author{
Syllable-timed languages
}

\section{Luiz Carlos Cagliari UNESP / Araraquara}

\section{Resumo}

Uma das questôes mais polêmicas da história da Fonética é, sem dúvida, a discussão sobre a tipologia rítmica das línguas. Fora da tradição greco-latina da versificação poética, a noção de ritmo foi confundida com a velocidade de fala, por muito tempo. No começo do século passado, surgiu a ideia da dicotomia entre língua de ritmo acentual e língua de ritmo silábico, também fortemente influenciada pela teoria da versificação poética. Nesse mesmo contexto, surgiu um terceiro tipo de língua, chamado de língua de ritmo moraico e aplicado quase exclusivamente ao japonês. Com as pesquisas acústicas e tratamentos estatísticos de dados gerados por análises eletrônicas computacionais da fala, a tipologia rítmica das línguas ficou mais confusa, com o surgimento de vários tipos de língua quanto ao ritmo. O presente trabalho discute algumas dessas ideias, mostrando que houve um grande equívoco por parte de alguns pesquisadores quanto à caracterização das línguas de ritmo silábico. A noção de moras é revisitada e seu papel é melhor definido nos estudos rítmicos da fala.

\section{Palavras-chave}

Ritmo da fala, Moras, História do ritmo da fala. 


\section{Abstract}

One of the most controversial issues in the history of Phonetics is the discussion about the typology of speech rhythm. Out of the Greek and Latin tradition on poetry versification, the notion of rhythm has been misunderstood as speech rate. In the early years of the 20th century, a dichotomy merged classifying the speech rhythm into stress-timed and syllable-timed languages, inspired by the old theory of poetic versification. Following the same old pattern, later on, a third type of language were proposed: the moraic languages, initially attributed only to Japanese. With the facilities to carry on acoustic research, in the second half of the 20th century, the typology of language rhythm came to a dead end. Different types of language were set out. This paper discusses these ideas, showing a great misunderstanding among researchers in relation to the characterization of a syllable-timed language. The notion of mora is revisited and its role in the study of speech rhythm is better defined.

\section{Keywords}

Rhythm, Mora, History of speech rhythm. 


\section{Preâmbulo}

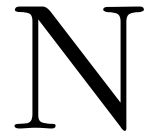

a História, algumas ideias desaparecem, ou porque ficam esquecidas, ou porque são substituídas por outras, tidas como mais vantajosas. $\mathrm{Na}$ história da Fonética, há um caso típico que se refere à tipologia rítmica das línguas, mais especificamente à ideia de ritmo silábico oposto a ritmo acentual. Nesse caso, ocorreram duas coisas: por um lado, houve o esquecimento de ideias importantes, pela falta de treinamento específico. A falta de habilidade em analisar e descrever os sons da fala levou alguns foneticistas a achar que o fenômeno não existia. Por outro lado, o fenômeno do ritmo da fala passou a ser tratado com outras tecnologias, cujos resultados mostraram outras realidades, as quais, por sua vez, se apresentaram como contraditórias ao que se tinha estabelecido antes.

Para alguém ser um músico cantor ou instrumentista, não basta a teoria; a pessoa precisa praticar muito, conhecer as sutilezas do ofício. Com a fonética, ocorre algo semelhante. Juntar interpretaçōes corretas por meio da percepção auditiva e da categorização dos fatos, de acordo com a ciência fonética, é uma tarefa árdua e, não raramente, não se aprende sozinho, mas sob a supervisão de alguém experiente. No final do século 19, quando começaram os estudos acústicos da fala, Paul Passy e Daniel Jones inventaram um modo específico de categorizar fenômenos segmentais e prosódicos, por meio do processo perceptivo, criando o Alfabeto Fonético Internacional (IPA), com a própria Associação Internacional de Fonética (IPA), porque eles viram nos estudos instrumentais da fala, sobretudo acústicos, um perigo de uso exclusivo de um modelo sobre outro. Ambos também trabalharam com a fonética experimental. Daniel Jones foi um dos primeiros foneticistas a criar um laboratório de fonética e a incentivar esse tipo de trabalho. Todavia, historicamente, não demorou muito para a fonética andar em dois caminhos paralelos: o da investigação auditiva e o da investigação instrumental, principalmente, voltada para a investigação acústica, por ser a mais barata, mais acessível e de mais fácil manuseio. A falta de diálogo entre as 
duas abordagens tem gerado um guerra entre dois grupos de foneticistas, com prejuízos para ambos. A falsa ideia de que um instrumental de trabalho como o PRAAT, o SFS, o WINPITCH, ou mesmo o PROTOOLS, dá as categorias e as funções linguísticas da fala através de um procedimento estocástico tem se disseminado. O PRAAT não sabe e nunca saberá o que é uma sílaba, porque a sílaba é fundamentalmente uma unidade do processo aerodinâmico da fala, e não do processo acústico: por exemplo, eu digo $b a-t a-t a$, mas poderia dizer $b a t-a$ $t a$, ou ba-tat-a: quem decide como o falante deverá dizer é o sistema da língua. Ao falar e ao ouvir, obviamente, outros fatores fonéticos integram a pronúncia, inclusive saliências acústicas de vários tipos. Porém, apenas olhando um espectrograma, não é possível dizer em que parte começam ou acabam as sílabas. ${ }^{1}$ Porém, ouvindo e, melhor ainda, falando, a categorização da fala em sílabas é clara e óbvia para qualquer linguista minimamente bem treinado. Estou insistindo em alguns aspectos teóricos das sílabas porque é de sua análise e interpretação que classificamos as línguas como sendo de ritmo acentual ou silábico.

Os estudos de prosódia da fala englobam vários aspectos (CAGLIARI, 1984, 1992, 2007a), tratados de modos diferentes por teorias e metodologias diferentes. Por exemplo, o modo como Pike (1945), Selkirk (1984), Nespor and Vogel (1986), Halliday (1973), Pierrehumbert (1980) etc. interpretam e analisam os fatos prosódicos da fala difere muito de um autor para outro. Neste trabalho, não é o caso de discutir tais teorias, nem de comentar sobre o valor de cada uma. Como todas as teorias trabalham com dados da fala, em princípio, deve haver certa uniformidade na determinação de certas categorias e funções. Por exemplo, noções básicas como sílaba, saliência melódica, duração segmental, pausa, volume, velocidade de fala, segmentação de unidades, etc., mesmo tratadas com outros rótulos ou pressupostos, devem fazer parte de todas as teorias prosódicas. Por essa razão, neste trabalho, elas não serão discutidas em detalhes e nem mesmo no geral.

O objetivo do presente trabalho é discutir uma questão bem específica: a noção de língua de ritmo silábico. Esse objetivo é muito relevante, uma vez que a definição do que vem a ser uma língua de ritmo silábico tem sido mal formulada, acarretando enorme discussão sobre a tipologia do ritmo das línguas (ROACH, 1982; WENK; WIOLLAND, 1982; WENK, 1987; DAUER, 1983). Por outro lado, a metodologia usada não é investigativa de um corpus linguístico, nem mesmo de um conjunto de dados, especialmente planejado para uma análise específica. $\mathrm{O}$ que se toma como relevante são as diferentes 
definiçôes de língua de ritmo silábico, analisando o que elas dizem, seus problemas e relevância. Os exemplos são apenas ilustrativos, esclarecedores dos comentários apresentados, não sendo fruto de uma pesquisa em profundidade. Por isso mesmo, é relevante o objetivo de colocar uma questão que não tem sido contemplada pelos estudiosos da tipologia do ritmo das línguas, como um argumento a mais na discussão e, certamente, como uma sugestão de pesquisas futuras.

\section{A noção de ritmo}

O ritmo é um fenômeno que sempre despertou grande interesse no ser humano. Desde os relatos mais antigos, desde as expressões corpóreas e manifestações artísticas dos mais antigos representantes da humanidade, o ritmo controla a vida. Há muitas explicações, provenientes de muitas áreas. Algumas pessoas acham que a sensação rítmica das batidas cardíacas seria a causa do interesse pelo ritmo, uma vez que elas indicam a vida e a morte. A estética da arte sempre foi explicada por um certo ritmo na música, na pintura, na escultura e na arquitetura. A ideia de simetria é uma ideia de ritmo agradável nas artes. Constatamos um certo ritmo em tudo o que vemos, ouvimos e fazemos. O ritmo não é exclusivo dos seres humanos: os animais também se veem envolvidos em ritmos, produzem ritmos e se guiam por eles. A própria natureza geológica tem seu ritmo. Nesse sentido, o ritmo é uma característica da vida e do ser, porque tudo está inserido no espaço e no tempo.

$\mathrm{O}$ ritmo pode ser definido de vários pontos de vista. Fisicamente, o ritmo é a repetição de um movimento ou evento, portanto, algo que estabelece uma relação espaço-temporal que se repete. Psicologicamente, o ritmo é uma sensação de uniformidade que se repete. Nas artes, o ritmo é uma forma de simetria. Do ponto de vista da música compassada, o ritmo é a quantidade de tempo definida pelo compasso. Na música do canto chão, o ritmo se confunde com o andamento, uma vez que as notas têm valores relativos de duração, dependendo da velocidade com que são executadas. Do ponto de vista da linguística cognitiva, podemos dizer que o ritmo é um modelo cognitivo idealizado (FERRARI, 2011, p. 50) controlado pelo frame espaço-tempo, por meio de um esquema imagético da repetição. Portanto, uma boa definição de ritmo, do ponto de vista cognitivo, é a expectativa da repetição. Todo objeto que ocorre seguindo um padrão repetitivo aciona a categoria ritmo na mente do indivíduo. $\mathrm{O}$ ritmo não é apenas uma 
medida física mas implica também um processo cognitivo. Esse modelo cognitivo pode referir-se a qualquer processo físico repetitivo. Desse modo, a interpretação do ritmo é tipicamente um processo mental, controlado pela expectativa da repetição. Na prática, o ritmo é verificável fisicamente por meio da constatação da repetição. Essa repetição pode ser totalmente regular, como quando um motor gera um ruído repetido em intervalos exatamente iguais ou isocrônicos; ou pode ser muito irregular, ocorrendo em intervalos previsíveis de algum modo, mas não em sequências exatas de intervalos de tempo. Em ambos os casos, o que identifica a presença de um ritmo é a expectativa mental de sua ocorrência. A natureza humana aceita facilmente um ritmo não isocrônico fisicamente, processando-o como mentalmente isocrônico. Ou seja, uma certa variação física dos intervalos é considerada irrelevante. Por outro lado, repetições rigorosamente isocrônicas são tidas como perturbadoras da ação mental, não raramente, levando os indivíduos a fugir delas. Essa experiência pode ser verificada na produção artificial de sons e até mesmo de músicas ou de falas.

\section{Música e fala}

A execução de uma partitura de orquestra exige um maestro para controlar o andamento da melodia, para que os músicos não mudem o andamento aleatoriamente. Um aprendiz começa a tocar com o metrônomo, mas não usa o metrônomo em apresentações musicais. A causa disso tudo é o processo mental de controle do ritmo. É por meio dele que julgamos uma música como tendo um mesmo ritmo, que é executado em velocidades diferentes, ou seguindo andamentos diferentes. Uma mesma melodia pode ser tocada em ritmos diferentes, não apenas com andamentos diferentes. Uma canção popular pode ser tocada como valsa, como samba, como tango, como jazz, rock, etc. Nesses casos, a mudança de ritmo leva consigo todas as implicações do novo padrão rítmico. Algumas pessoas se perturbam mais com mudanças de ritmo do que com pequenas desafinações ou portamentos. Isso ocorre porque além de o indivíduo ter uma expectativa de como um ritmo deva ser executado, ele tem uma expectativa de com qual ritmo a peça deva ser executada. A experiência de vida das pessoas interioriza essas expectativas na mente.

O ritmo da fala é semelhante ao ritmo da música. ${ }^{2}$ Com relação à expectativa de repetição de saliências marcadas, o que se aplica à música aplica-se à fala ${ }^{3}$ (SHEN; PETERSON, 1962; O'CONNOR, 1965; PATEL; DANIELE, 
2003). Quando se marca o ritmo nas batidas das notas musicais para manter o ritmo, a duração dos compassos precisa ser montada de modo a gerar essa regularidade. Todavia, como vimos, essa regularidade é "teórica" ou "abstrata", porque vai depender do andamento ou velocidade de execução nos vários compassos estabelecidos e do ponto de vista da realização física. Seria estranho esperar que a execução da música fosse realizada exatamente conforme a partitura, em termos da duração física expressa pelos compassos. O metrônomo é um aparelho de treinamento, nenhum artista toca uma peça acompanhado do metrônomo, com exceção, talvez, de experiências musicais do tipo música eletrônica. Os aparelhos que vem com as baterias eletrônicas complicam mais do que ajudam o músico. Todavia, o andamento não pode ser feito de modo a destruir a expectativa rítmica que se tem da música. Embora se possa fazer uma peça musical com compassos variados ao longo do tempo, tal tipo de música é considerada muito diferente e fora das expectativas comuns. Em geral, essa execução soa como algo truncado na linha do tempo, uma espécie de "gagueira" musical. No caso do canto chão, as notas indicam a altura melódica, não a duração. Em geral, admite-se que elas sejam ou longas, ou breves, ou mesmo de durações iguais. $\mathrm{O}$ andamento de execução irá indicar a proporção duracional entre elas e o desenvolvimento de um certo ritmo, baseado na duração atribuída a cada nota. No caso do canto gregoriano, por exemplo, como o texto costuma ser em latim, e essa língua apresenta oposição fonológica de sílabas longas e breves, o canto gregoriano segue esse padrão rítmico. Uma estratégia musical, ainda no canto gregoriano, é colocar em sílabas longas latinas duas ou mais notas, contrastando com as anteriores e seguintes. Mas esta regra não é geral, pelo contrário, é dependente do tipo de ritmo que se quer dar à musica. Por exemplo, em final de frases melódicas, sílabas breves latinas podem vir associadas a várias notas. Na verdade, a música depende muito mais da natureza fonética das palavras do que se costuma pensar. Quando a música cantada não bate com a estrutura da língua, o canto pode trazer resultados que logo chamam a atenção do ouvindo como sendo estranhos. ${ }^{4}$

\section{Da poesia para a prosódia: descobrindo o ritmo da fala}

A invenção da escrita representa a mais antiga reflexão sobre a fala. Quer se trate de escrita ideográfica ou fonográfica, a representação da fala está sempre presente, de um modo ou de outro. Certamente, a identificação linguística das 
palavras foi a primeira coisa a ser levada em consideração, sendo até hoje a unidade básica fundamental de todo tipo de escrita (CAGLIARI, 2009).

Independentemente da escrita, o ser humano fala, grita, cantarola e canta. Além disso, o andar, o gesticular, o bater um objeto em outro são formas de observar o comportamento do som, incluindo a maneira como se repete, ou seja, o ritmo. A associação da fala com a música ou com o ritmo criou um tipo especial de texto, que chamamos de poesia. A simetria entre trechos repetidos constituiu um elemento definidor da poesia. Quando a escrita chegou, já havia uma prática de produção de poesia. A invenção da escrita não foi motivada pela poesia, mas pela necessidade de memorizar registros de contabilidade, algo mais próximo da sobrevivência. Mas não demorou para ela memorizar também outras formas da expressão da linguagem. Em se tratando de elementos culturais relacionados com a linguagem, os textos mais antigos foram produzidos quase que exclusivamente em forma poética. Um padrão rítmico marcante, sem dúvida alguma, que tinha como função facilitar a memorização e a leitura em voz alta. Essa preocupação com o ritmo da fala, traduzida em uma forma de texto poético, foi influenciada pela escrita também, não ficando apenas como uma realização oral. Ao longo da longa história da escrita, tal fato é notável, como mostram os estudos literários.

Assim, de todas as formas poéticas portadoras de esquemas rítmicos bem definidos, na nossa tradição ocidental, a poesia grega antiga é a referência antiga mais conhecida. O caráter fonético dessa poesia não tem sido muito estudado, mas há referências de escritores antigos, contemporâneos da produção dessas poesias, bem como de gramáticos e estudiosos, apresentando de modo geral ou mesmo detalhado como aquela poesia era estruturada.

O padrão rítmico da poesia grega antiga tinha, como elementos constitutivos prosódicos: o verso (utterance), o grupo tonal (frase entoacional), os pés (frase fonológica), o metro (palavra fonológica), as moras (duração silábica) e as pausas delimitando espaços rítmicos necessários (respiração), desejáveis (ênfase) ou possíveis (para evitar esquisitices). A repetição de padrōes (pés) deixava claro o ritmo. Estes podiam variar de poesia para poesia, mas, dentro de uma mesma poesia, deviam se manter constantes, justamente para mostrar a estrutura rítmica com repetição. Na verdade, toda fala traz consigo todos esses elementos; o que distingue a poesia da prosa é o modo como esses elementos são organizados no texto (CAGLIARI; MASSINI-CAGLIARI, 1998). Os elementos prosódicos são primeiramente elementos da fala e, depois, elementos constitutivos da poesia. 
A arte poética sempre privilegiou versos curtos, porque a marca rítmica é mais saliente. Versos muito longos assemelham-se à prosa, no que tange a prosódia. Da simetria rítmica dos versos no poema tem-se uma poesia mais rigidamente estruturada com relação à prosódia. Nesse sentido, muitos poetas gregos antigos foram exímios realizadores de poemas rigorosamente simétricos com relação aos elementos rítmicos (ALLEN, 1973).

\section{Da poesia para a prosa: as mesmas unidades rítmicas}

O modelo descritivo da poesia grega antiga passou para o latim e para as línguas derivadas. Outras línguas também apresentaram textos ritmados poeticamente. Todas as línguas, entretanto, apresentam os elementos prosódicos fundamentais, como moras (duração silábica variável), as palavras (lexicais e fonológicas), as frases entoacionais ou grupos tonais e o enunciado (um ou mais grupos tonais) (NESPOR; VOGEL, 1986; CAGLIARI, 1982, 1992). Como foi dito antes, a grande diferença reside no modo como esses elementos prosódicos são organizados no texto.

Ravizza (1940, p. 406, parágrafo 522) diz:

Chama-se quantidade das sílabas o maior espaço de tempo gasto na prolação de umas sílabas em relação a outras do vocábulo. As sílabas dividem-se em duas classes principais: breves $(\cup)$ e longas (-). A diferença fundamental destas duas classes de sílabas consiste em que a longa era considerada como o duplo da breve, ainda que a proporção não fosse sempre absolutamente rigorosa. A breve valia uma unidade de duração (mora), isto é, 1/8 de compasso ordinário, a longa normalmente duas... Algumas sílabas podem ter uma ou outra quantidade e dizem-se comuns $\leftrightharpoons$ ou $こ$.

Exemplos: longa: nāvis; breve: bŏnus; comum: tenebrae (síl. ne $\longleftarrow$ ). $\mathrm{Na}$ citação de Ravizza, aparece uma informação muito importante. Segundo ele, um pé métrico (compasso ordinário) teria 8 tempos, sendo a breve equivalente a $1 / 8$. As sílabas longas variavam, podendo ter valores de $2 / 8,3 / 8,4 / 8$ e 5/8. Com essas medidas, um verso latino podia ser declamado com um padrão duracional semelhante ao da música com compassos. Os estudos prosódicos greco-latinos antigos diziam que a quantidade era atribuída à sílaba, mas tinham regras que 
contemplavam as vogais como ponto de referência primária. Em primeiro lugar, a quantidade podia ser atribuída por natureza (caráter fonêmico distintivo, lexical) ou pelo contexto. Veja algumas regras, a seguir: 1) Todo ditongo tem uma vogal longa por natureza: aurum, paena. 2) Toda vogal diante de outra vogal (sem ser ditongo) é breve por natureza: Deus, puer. 3) Toda vogal diante de duas consoantes é longa por posição: carmen, hostis. A metodologia greco-latina foi usada por Jerônimo Soares Barbosa em sua Gramática Filosófica (1822). A esse respeito, veja os trabalhos de Cagliari (1985).

Os valores propostos por Ravizza ou que se costumam atribuir às moras latinas não significam que sempre terão fisicamente valores absolutos, exatos e constantes. A mesma coisa ocorre com a música: as notas têm valores matematicamente determinados, mas, na prática, somente a música feita eletronicamente consegue manter os valores das notas rigorosamente constantes. Porém, os músicos detestam isso, achando que a música fica sem graça. $\mathrm{Na}$ fala, ocorre algo semelhante: é possível fazer sinteticamente enunciados com os valores exatos das moras, mas tal realização não é possível na fala, nem é desejada, porque a pequena variação que ocorre ajuda a tornar a pronúncia mais natural. Na música, a mesma tolerância ocorre com relação à duração das notas. Esse é um comportamento típico da mente humana, controlando sistemas complexos. ${ }^{5}$

$\mathrm{Na}$ Gramática Castelhana, o autor, Antônio de Nebrija (1492), ${ }^{6}$ reconhece que a fala tem os mesmos ingredientes rítmicos e prosódicos das poesias e que ele iria escrever um tratado a respeito. No entanto, eu nunca consegui achá-lo. Ele pode não ter feito. Porém, um poeta português, Antônio Feliciano de Castilho (1850), fez a investigação sugerida por Nebrija (1492) e mostrou como a fala e a poesia compartilham dos mesmos elementos prosódicos, porém, organizados no texto de modos diferentes. Essa ideia é comumente aceita pelos linguistas: as teorias prosódicas referem-se a fatos da fala em geral, quer sejam prosa, quer sejam poesia (CLASSE, 1939; CRYSTAL, 1975). A poesia é uma segunda organização prosódica, sobre uma organização da fala comum da língua, e não pode desrespeitar o sistema prosódico próprio da língua (ABERCROMBIE, 1965; CAGLIARI, 1984). Entretanto, historicamente, a teoria poética nem sempre esteve de acordo com a teoria prosódica geral das línguas. Modelos de grande prestígio, oriundos de determinada produção literária famosa de certas línguas, não raramente servem de exemplos para outras línguas, mesmo quando estas têm características prosódicas e, sobretudo, rítmicas muito diferentes. A 
passagem do modelo grego antigo para o latim era natural e simples, porque ambas as línguas compartilhavam de sistemas rítmicos semelhantes. Porém, esse mesmo modelo, devido a seu prestígio, foi passado para outras línguas europeias (e até não europeias), criando padrões poéticos incompatíveis com o sistema prosódico e, principalmente, rítmico da língua importadora do modelo. Não raramente, os poetas dessas línguas se viram em situações de grande dificuldade ou mesmo de impasse. Alguns conseguiram conciliar modelos aparentemente contraditórios, outros, simplesmente fizeram poemas para serem vistos, e não para serem ouvidos, com relação à estrutura prosódica, incluindo o ritmo.

\section{Saliências rítmicas}

Quando se estuda uma língua, o problema do linguista é o fato de todos os elementos dos diferentes níveis de análise aparecerem juntos, ao mesmo tempo. O trabalho do linguista é separar categorias e funções, analisá-los, interpretá-los, sem perder de vista o todo. Alguns fenômenos linguísticos estão mais imbricados em outros, o que torna a análise mais complicada. $\mathrm{O}$ ouvido humano é capaz de isolar vários parâmetros de uma onda acústica: por exemplo, separamos bem a voz do cantor do som do conjunto que o acompanha. Mas, dificilmente distinguimos pelo ouvido as frequências dos formantes. Um programa como o PRAAT consegue identificar os formantes, a variação melódica do fundamental (pitch) e medir o tempo com precisão, mas não separa a voz do cantor e dos instrumentos. O ouvido trabalha diretamente com a mente do falante, mas o PRAAT apenas dá informações acústicas. A interpretação será um processo mental, portanto, de natureza fonológica, se a análise tem objetivos linguísticos de descrever o sistema de uma língua.

O ritmo é um fenômeno que depende mais da mente do falante do que de medidas exatas, colhidas no sinal acústico. $\mathrm{O}$ ritmo depende da velocidade com que cada unidade fonética é pronunciada e da identificação de saliências fonéticas, tudo interpretado fonologicamente; ou seja, o ritmo é um fenômeno idealizado na mente do falante, mas que tem apoio na percepção auditiva e até nos mecanismos articulatórios de produção e de percepção dos sons da fala. É um fenômeno envolvido com o mecanismo aerodinâmico da fala, com a duração articulatória dos segmentos, com a categorização temporal das unidades de fala (LEHISTE, 1970), com a produção e percepção desses elementos e, finalmente, 
é um fenômeno comprometido com o sistema sonoro da língua (PIKE, 1945; ABERCROMBIE, 1965a; ALLEN, G. D., 1975; CAVALCANTE PROENÇA, 1955; CAGLIARI, 1984; CRYSTAL, 1969; ULDALL, 1971, 1972).

Do ponto de vista aerodinâmico, ${ }^{7}$ o ritmo depende do volume de ar pulmonar controlado para a fala, produzindo unidades com mais ou menos intensidade ou volume sonoro (MASSINI-CAGLIARI; CAGLIARI, 2000, p. 107-110). O mecanismo aerodinâmico também é responsável pelos pulsos torácicos que formam foneticamente as sílabas (STETSON, 1928). Estas são unidades importantes na definição do ritmo. Toda sílaba apresenta uma estrutura com consoantes e / ou vogais. Do ponto de vista da saliência, as vogais são os elementos em destaque, ao passo que as consoantes ocorrem com menos saliência, com algumas raras exceçôes, em certos contextos: numa palavra isolada como osso, a fricativa é mais saliente do que a vogal - compare com assa. Numa palavra como pato ou pata, as duas consoantes não apresentam saliência por si, sendo identificadas apenas na transição das vogais adjacentes (loci). Na prática, as vogais predominam sobre as consoantes e, portanto, são suscetíveis de imprimir maior saliência auditiva às sílabas. Por causa disso, alguns foneticistas, como Cagliari (1980), propuseram que a medida rítmica entre os pés métricos fosse contada do centro de uma vogal tônica para o centro da próxima vogal tônica, ou mesmo do início de uma vogal tônica até o início da próxima vogal tônica e não a partir do início da sílaba. Essa proposta tem a ver com a percepção do ritmo: marcando o ritmo da música com sílabas do tipo pa-pa..., as batidas ocorrem sempre no início da vogal e se prolongam, dependendo da duração da nota. Na fala, ocorre a mesma coisa, se fizermos um teste com palavras de estrutura fixa e repetitiva, como em: pato, mato, cato, fato, chato, nato, rato; claramente, as batidas rítmicas ocorrem no início da vogal e se prolongam durante sua duração longa, até atingir a sílaba seguinte, repetindo o processo sucessivamente. Esse é o modo como marcamos o ritmo da fala auditivamente. ${ }^{8}$

O mecanismo aerodinâmico é responsável também pelo controle da duração das sílabas e de seus elementos constitutivos. Assim como na música, temos notas mais longas ou mais breves; do mesmo modo, encontramos na fala segmentos mais longos ou mais breves, sílabas mais longas ou mais breves. $\mathrm{Na}$ música, há uma medida matemática para definir as duraçōes das notas (mínima, semínima, colcheia, etc.). Na fala, a duração das sílabas depende da duração de seus elementos constitutivos. Esses elementos variam muito e, portanto, o 
resultado final da duração de uma sílaba agrega valores variáveis. Por exemplo, uma consoante surda pode ser mais longa do que uma consoante sonora, um tepe tem uma duração muito breve, uma consoante fricativa na coda final de uma palavra tem uma duração maior do que no onset inicial de uma palavra, a vogal tônica de uma palavra pode ter valores variados em diferentes contextos em que essa palavra ocorre. Por essa razão, nas análises prosódicas, a duração individual dos segmentos não tem sido considerada relevante para a análise linguística. Porém, para os estudos do ritmo, a duração silábica é uma medida que sempre foi considerada de grande relevância. $\mathrm{O}$ mecanismo aerodinâmico agrega os segmentos em sílabas e não os trata individualmente. O que vai criar os segmentos são os procedimentos articulatórios da fala (MASSINI-CAGLIARI; CAGLIARI, 2000, p.108). Assim, com um exame de cinestesia, o falante é capaz de sentir como articula os segmentos da fala, incluindo sua duração. Por outro lado, por meio de um processo de empatia fonética, o ouvinte reproduz os mecanismos articulatórios produzidos pelo falante e, desse modo, pode sentir o que ouve, como se ele os pronunciasse. Esses mecanismos conferem ao processo de fala, envolvendo o falante e o ouvinte, uma comunicação fonética específica, padronizada no corpo e na mente. É por isso que sempre falamos do "mesmo jeito" e esperamos que os demais falantes da língua o façam assim. Se algo sair errado, isso será logo percebido como estranho pelo falante e pelo ouvinte.

A duração das sílabas tem sido interpretada com uma escala de valores que compreende sílabas: iguais ou diferentes; as sílabas diferentes são: ultrabreve, breve, média, longa, ultralonga. Outros valores maiores ou menores têm sido considerados irrelevantes linguisticamente. ${ }^{9}$ Sílabas iguais ocorrem em certos casos e contextos e só são tratadas assim quando há uma sequência de muitas sílabas iguais. Nenhuma língua usa só sílabas iguais. Todas as línguas apresentam variações nas durações das sílabas como regra sistemática. Na prática, há muitos padróes de variação que podem ocorrer. Uma língua como o francês tem nas sílabas com 'chuá' uma duração mais breve sistematicamente. Uma língua como o espanhol tem nas sílabas tônicas finais de grupos tonais uma duração sistematicamente mais longa. No geral, essas duas línguas tendem a ter sílabas iguais em sequências relativamente longas.

Um modo prático de definir as durações das sílabas ou moras (CAGLIARI, 2007, p. 135-136), seguindo uma tradição greco-latina da versificação, é usando duas categorias: a das sílabas longas, que podem ser longas ou ultralongas e a categoria das sílabas breves, que podem ser breves ou ultrabreves. As sílabas médias ficam 
restritas a sequências de sílabas que não se caracterizam por ser longas nem breves. Mesmo em grego e em latim, em alguns contextos não havia oposição fonológica entre longa e breve. A duração era prevista por uma regra contextual.

\section{Um modelo cognitivo na mente controla o falante e o ouvinte}

Do ponto de vista da verificação da duração das sílabas, o modelo acústico mostra valores físicos, medidos em milissegundos. A variação é grande, mas dentro de certos limites, caso contrário, tem-se uma fala estranha. Essa expectativa de normalidade é facilmente detectada pelas análises auditivas, que padronizam a variação em categorias bem definidas pelo sistema da língua e interiorizadas pelos falantes nativos. Enquanto a acústica precisa de um tratamento estatístico para revelar categorias e desvios, a análise auditiva trabalha apenas com valores idealizados, do tipo longo oposto a breve. Em um grau de delicadeza maior, com categorias mais específicas, a duração pode ser interpretada com os cinco valores apresentados anteriormente. Certamente, o ouvido é capaz de ir além, como o faz com as notas musicais. Mas, na fala, tal detalhamento é irrelevante, porque o sistema da língua, nesse caso, opera de modo diferente do sistema da música. A música tem um som prolongado (notas) com valor melódico constante. A fala, por sua vez, tem um gradiente de variação sonora, decorrente dos movimentos articulatórios em constante movimento, passando de uma articulação para outra. Esse fator gradiente distingue claramente a fala da música. Uma pessoa pode desafinar no canto, mas dificilmente encontramos uma pessoa desafinando quando fala.

Se quisermos ir mais longe com a análise auditiva, podemos usar uma escala de percepção, Por exemplo, se uma sílaba longa dura 1, uma sílaba breve dura $1 / 2$, uma sílaba ultrabreve dura $1 / 4$; uma sílaba ultralonga dura 2 , seguindo uma escala em que um valor superior é o dobro do valor imediatamente inferior (uma sílaba média pode ter qualquer duração). Com essas medidas, podemos comparar a análise acústica do tempo das sílabas com a análise auditiva das moras. Não somente na análise acústica não encontramos padrões rígidos de durações para as sílabas, fato claramente mostrado por análises estatísticas. como nessa comparação entre valores auditivos e medidas físicas da duração das sílabas, não encontramos padrôes exatos. Há outros fatores relevantes para a interpretação auditiva das moras. 
Para entender essas diferenças entre fatos físico-acústicos da fala e modelos interpretativos, é preciso, em primeiro lugar, distinguir uma análise física de um objeto sonoro (que, por acaso, é a fala), de uma análise linguística, baseada em um sistema que controla tudo para que os sons da fala representem sons de uma linguagem ou língua. Portanto, estamos diante de três momentos de interpretação da fala: 1) o momento físico, definido por meio de aparelhagem de alta precisão; 2) o momento linguístico que elabora padrões sobre o que o falante diz e sobre o que o ouvinte interpreta, para que haja uma igualdade, de modo que a comunicação seja realizada de modo correto; e 3) o momento cognitivo que define um padrão cognitivo idealizado na mente dos falantes, construído a partir da sensação corpórea dos movimentos da fala, elaborando padrões relacionados com os domínios do tempo e do espaço, com a finalidade de imprimir ao material sonoro da fala (frame) categorias prototípicas. ${ }^{10}$ Assim, o falante produz a fala de modo controlado por limites categoriais da qualidade sonora e do tempo e o ouvinte interpreta o que ouve em função desses mesmos parâmetros, ambos tendo como alvo a correta comunicação da mensagem linguisticamente elaborada, de acordo com o sistema da língua. Na verdade, é somente no nível cognitivo que podemos analisar a linguagem, no geral e no particular, porque ela é tipicamente um sistema complexo, no sentido da linguística cognitiva. Desse modo, fica claro que não se pode medir duração e ritmo fora da mente dos falantes, sob risco de não se chegar à conclusão nenhuma. A história recente dos estudos sobre ritmo tem mostrado isso claramente e à exaustão. Num determinado momento, perdeu-se o essencial, ficando com o acidental e, com isso, as conclusões acabaram falseando a realidade.

\section{Revendo os tipos de língua quanto ao ritmo}

Muito se tem escrito a respeito do ritmo das línguas. Alguns acham que as línguas se dividem em dois grupos apenas, dadas as restriçóes do processo aerodinâmico, produzindo as sílabas com suas características de duração e de tonicidade (PIKE, 1945; ABERCROMBIE, 1967, p. 24-25; CATFORD, 1977; HALLIDAY, 1970; CAGLIARI, 2007; HALLIDAY; GREAVES, 2008). Outros acham que se pode medir o ritmo por meio de algoritmos que controlam a variação duracional das sílabas nos enunciados, medidas com exatidão, com análises computacionais de espectrogramas dos sons da fala, cujos resultados mostram várias tendências rítmicas e, portanto, vários tipos de línguas quanto 
ao ritmo. Apareceram estudos mostrando que as línguas tendem para um lado ou para outro e que, assim, tem-se uma variedade de tipos de línguas quanto ao ritmo (BARBOSA, 2004, 2006, 2012). Estudando a fala do japonês, alguns foneticistas classificaram essa língua como sendo de um tipo especial, chamado língua de ritmo moraico (PORT; DALBY; O’DELL, 1987; WARNER; ARAI, 2001). ${ }^{11}$

\subsection{A ação do sistema fonológico: produzindo e interpretando o ritmo}

Levando em conta o exposto acima, fica claro que os falantes interpretam o fenômeno do ritmo como resultado de um modelo cognitivo idealizado, cuja realização no mundo externo à mente se faz pelos mecanismos de produção da fala. Foneticamente, a sílaba é um produto do mecanismo aerodinâmico, que gera um padrão linguístico formado de unidades tônicas e átonas, pela variação de intensidade da corrente de ar fonatório por meio de uma respiração modificada (MASSINI-CAGLIARI; CAGLIARI, 2000, p. 108), produzindo sequências de pulsos respiratórios, cada qual com determinada duração e intensidade aerodinâmica (CATFORD, 1977, p. 63-92, 239-246; LAVER, 1994, p. 161-183). Isso mostra que é evidente que podemos estabelecer dois e apenas dois tipos de padrões rítmicos para a fala: um padrão baseado na duração, e outro, na intensidade dos pulsos aerodinâmicos, ou seja, nas moras lexicais e nas sílabas tônicas, reestruturadas no nível dos enunciados. Por exemplo, a palavra batata tem uma sílaba breve, uma longa e uma breve; a palavra lâmpada tem uma sílaba longa, seguida de duas breves, a palavra flúor pode ser pronunciada com uma breve e uma longa (a primeira tônica e a segunda átona) e assim por diante.

Em algumas línguas, os padrões duracionais das sílabas são transferidos do léxico para a fala, gerando oposiçôes fonológicas pela relativa duração de cada sílaba. É o caso de algumas línguas de ritmo silábico, do tipo do grego, e do latim. Essas línguas preocupam-se com as oposições fonológicas de duração. ${ }^{12}$ Outras línguas, do tipo do francês, espanhol, japonês, alemão, também de ritmo silábico pela sua natureza, transferem para a fala duraçôes silábicas de valores iguais em longas sequências de sílabas, e introduzem, em determinados contextos, sílabas com valores duracionais diferentes: breves ou longos, para definir processos fonológicos contextuais específicos. ${ }^{13}$ Por outro lado, o mecanismo aerodinâmico pode também manter um padrão relativo de duração 
silábica, com valores proporcionais aos padrões definidos para as palavras no léxico da língua, mas comprimir ou alongar o espaço entre as sílabas tônicas à moda de uma mola, quando colocadas em enunciados. Nas línguas, essa adaptação da duração lexical à marcação de compassos não destrói os padróes moraicos lexicais das sílabas, porque mantém a proporção duracional das sílabas marcadas nos itens lexicais; se houvesse uma mudança nas moras lexicais, as palavras soariam estranhas. Esse tipo de língua é chamado de língua de ritmo acentual, como o inglês, o português, o árabe.

As línguas de ritmo silábico são menos sensíveis linguisticamente ao andamento e à velocidade de fala, razão pela qual sofrem menos processos fonológicos que modificam a forma fonética. Porém, as línguas de ritmo acentual são muito sensíveis ao andamento e à velocidade da fala, manifestando comumente muitos processos fonológicos (queda, epêntese, sândi, assimilação, etc.), atuando de modo notável. Pelos processos fonológicos, tem-se boas indicações sobre o tipo de ritmo que a língua tem.

\subsection{A invariância na variação}

Nesse momento, é imperativo fazer um esclarecimento. Uma língua como o inglês e o português, por exemplo, são faladas em muitos lugares, com características locais próprias, o que dificulta colocar todas as análises das falas desses dialetos sob um mesmo rótulo. Um escocês típico fala inglês com ritmo silábico, diferente de um inglês típico que fala inglês com ritmo acentual. ${ }^{14} \mathrm{O}$ português de um paulista é tipicamente uma língua de ritmo acentual, mas o português de um gaúcho de fronteira é tipicamente uma língua de ritmo silábico (CAGLIARI; ABAURRE, 1986). Aqui, como sempre, é preciso saber exatamente a que sistema linguístico pertence um falante. $O$ rótulo mais geral de uma língua serve a muitos propósitos e não pode ser desculpa para criar um caos nas interpretações linguísticas, porque as diferenças dialetais, em alguns casos, são muito grandes, definindo sistemas linguísticos paralelos de uma mesma língua, por exemplo, uma língua pode ser falada com tipos diferentes de ritmo. ${ }^{15}$

Além da variação dialetal, nenhum falante de língua de ritmo acentual grita usando um esquema de ritmo acentual, mas silábico, produzindo sílabas de igual duração. Como ocorre uma modificação drástica nas moras, o não estranhamento do falante é uma evidência de como ele processa mentalmente o ritmo de sua língua, levando em conta esses fatores contextuais. Também não se faz súplicas ou pedidos 
enfáticos, usando o ritmo acentual, mas se fala com um ritmo silábico, em geral, com sílabas iguais. Certos modos de falar também são apresentados com ritmo silábico, mesmo por um falante de língua de ritmo acentual, por razōes estilísticas. A teoria poética de versificação do português assume a língua como sendo de ritmo silábico, uma vez que os versos são definidos pelo número de sílabas. Essa teoria induz alguns falantes a lerem poesias com ritmo silábico, e não com ritmo acentual, típico de sua língua (ABERCROMBIE, 1965; CAGLIARI, 1984).

\subsection{Aquisição do ritmo na aquisição da linguagem}

É notório que as crianças comecem a falar por meio de um balbucio, que consiste em uma repetição de sílabas (ba-ba-ba), que variam de altura melódica, mas costumam variar pouco inicialmente com relação à duração (sílabas médias ou iguais, não sendo nem longas nem breves). Portanto, as crianças começam sempre com um ritmo silábico. ${ }^{16}$ À medida que aparecem as primeiras palavras, o léxico vai se formando e a duração das sílabas das palavras começam a se fixar no sistema da criança, com valores determinados pela língua.

\subsection{Isocronia revista}

$\mathrm{Na}$ literatura, a questão da definição do tipo de ritmo ficou ainda mais confusa com relação às línguas de ritmo silábico, em particular, porque muitos aplicaram uma noção de isocronia, achando que todas as sílabas devessem ter uma mesma duração sempre. Essa afirmação nunca foi feita nesses termos nem era essa a intenção dos foneticistas que classificaram as línguas em dois tipos. Historicamente, as línguas de ritmo silábico mais típicas são o grego e o latim clássicos, que tinham sílabas longas e breves em sequências variadas que formavam os pés métricos. Como a duração das sílabas nessas duas línguas era fonologicamente contrastiva, criava fonemas cuja variação duracional podia mudar o sentido das palavras, razão pela qual, não podiam transformar esse padrão rítmico em um padrão típico de línguas sem oposição fonológica pela duração silábica. Esse padrão rítmico explica por que o grego e o latim não tinham poemas com rimas. Estas só foram aparecer na Idade Média. ${ }^{17}$ No léxico das línguas de ritmo silábico, os falantes também têm a sensação de saliência variada entre as sílabas das palavras. Uma palavra com o padrão iâmbico dá a sensação de uma palavra oxítona, com um padrão trocaico tem-se a sensação de uma palavra paroxítona, 
assim como uma palavra com padrão datílico dá a sensação de uma palavra proparoxítona. ${ }^{18}$

No léxico das línguas de ritmo acentual, a saliência tônica é marcada pelo acento, que pode se realizar foneticamente por uma sílaba mais longa, mais forte ou mais aguda, não sendo esses parâmetros exclusivos uns com relação aos outros (MASSINI-CAGLIARI, 1994; REIS, 1995). A tonicidade vem da maior ou menor intensidade do ar fonatório no processo aerodinâmico. A variação gera sílabas mais intensas ou menos intensas. Associada à duração, uma sílaba é mais tônica ou menos tônica. Essa tonicidade é lexical. No enunciado, a tonicidade é reforçada ou diminuída pela variação melódica da fala (entoação). A eurritmia é criada no léxico e reforçada ou não no enunciado, por exemplo, gerando vários graus de tonicidade (cf. as grades métricas).

Numa língua de ritmo silábico, como o espanhol, a tonicidade é menos evidente e menos importante do que numa língua de ritmo acentual, como o português. Para todas as línguas, a tonicidade é importante na marcação do foco prosódico do grupo tonal, ${ }^{19}$ mas não nas demais palavras do enunciado. Como um enunciado pode se reduzir a uma simples palavra, os acentos, nesses casos, são os mesmos que o sistema atribui à sílaba saliente do foco num enunciado, fato que costuma ocorrer na última sílaba tônica (foco não marcado, neutro - HALLIDAY, 1976). Como foi dito acima, essa marca acentual define a tonicidade das palavras isoladas no léxico, razão pela qual reconhecemos facilmente uma sílaba tônica em uma palavra isolada com mais de uma sílaba. A tonicidade de uma sílaba e sua mora só podem ser definidas em contraste de uma sílaba com outra, em posição contígua. Se a palavra tiver apenas uma sílaba e for pronunciada isoladamente, não se pode saber se ela élonga ou breve, tônica ou átona. Certamente, pelos modelos idealizados na mente, os falantes, baseando-se em sua experiência e no sistema fonológico da língua, podem atribuir a priori um valor lexical acentual ou moraico mesmo à uma palavra monossilábica. Em um enunciado longo, essa tonicidade e o valor moraico são reestruturados em função da tonicidade ou da definição moraica para contextos específicos: há regras de atribuição de acentos e de moras.

Um problema semelhante ocorre com o esquema acentual das línguas de ritmo acentual. A tonicidade lexical não é transportada para cada palavra do enunciado automaticamente, como nas línguas de ritmo silábico, mas é reestruturada na formação dos pés rítmicos. Essas ocorrências de tonicidade só podem ser descritas por meio da análise auditiva ou recorrendo ao sistema idealizado pelos falantes, ou seja, por uma razão fonológica, e jamais por meio 
de análises acústicas, com ou sem tratamento estatístico. Além disso, variações do andamento ou da velocidade de fala podem alterar o esquema acentual e moraico. Por exemplo, no nome Luís Carlos da Silva, o nome Luís é tipicamente pronunciado com duas sílabas átonas, como se Luiz Carlos fosse uma palavra só. $\mathrm{O}$ acento cai em Car- e em Sil-. Num enunciado como Mariana gosta de bolo quente, podemos ter vários esquemas acentuais. Fora o acento em - $a$ - de Maria-na e em gos- de gos-ta, o sintagma bolo quente pode ter a primeira palavra átona e a segunda tônica (quen-), ou a primeira palavra tônica (bo-) e a segunda átona, ou mesmo, numa fala vagarosa ou por motivos de ênfase, pode-se ter as duas palavras acentuadas (em bo- e em quen-). Esses grupos acentuais formados no enunciado não são a simples soma de itens lexicais, cada qual com seu acento, mas formam palavras fonológicas à moda dos nomes próprios. ${ }^{20}$

Quando ocorrem muitas sílabas átonas entre duas tônicas, principalmente em enunciados longos, as sílabas átonas tendem a ser muito breves e de valor semelhante - em línguas de ritmo acentual. No entanto, por questôes de eurritmia, a variação entre elas pode ocorrer, criando acentos secundários de vários níveis (CÂMARA, 1985, p. 36-39; ANDRADE; LAKS, 1991). As unidades prosódicas como as moras e os pitch accents $(\mathrm{H}, \mathrm{L})$ nunca ocorrem com valores iguais: ocorre uma modulação ao longo do enunciado, para não tornar a fala monótona. Isso é muito evidente vendo nos espectrogramas as moras das sílabas e suas saliência entoacionais.

Mesmo em uma língua de ritmo acentual, como o português, a recorrência de uma mesma palavra em diferentes contextos costuma ter valores duracionais constantes, se a formalidade da fala e o andamento não se alterarem. Todavia, esses valores não são exatamente iguais. O que é exatamente recorrente e constante é o padrão moraico. Por exemplo, analisando várias ocorrências do nome Heitor, constatou-se pequena variação no tempo e na tonicidade lexical, medido acusticamente, mas todas as realizações trazem nitidamente o padrão moraico: breve / longa. Esse padrão representa o modelo idealizado na mente, ou seja, o padrão lexical da palavra no sistema da língua. Porém, quando o nome é destacado por alguma razão (por exemplo, é o foco, ou o tópico), o padrão mais comum é: sílaba ultrabreve / sílaba ultralonga, para evidenciar mais o foco. Mas, se o nome for dito como uma palavra isolada, pode-se ter claramente um padrão de duas sílabas iguais. Nesse caso, não se pode dizer que elas sejam longas ou breves, na comparação. O processo de passagem do léxico para o enunciado é, pois, semelhante nos dois tipos de ritmo, mas são implementados de modos diferentes. 


\section{Ilustrando alguns fatos}

Como foi dito no início deste trabalho, o objetivo é fazer considerações de natureza teórica sobre a dicotomia rítmica das línguas, discutindo, em particular, o que caracteriza uma língua de ritmo silábico. Ficou claro que não se pode discutir tipologia rítmica da fala sem levar em conta o esquema moraico das sílabas, a tonicidade e o andamento. Para a compreensão das línguas de ritmo silábico, o mais importante é o esquema moraico. Não constitui objetivo deste trabalho apresentar uma investigação prática de análise de línguas. Esse é um projeto que ainda precisa ser feito dentro da abordagem metodológica apresentada no presente trabalho. Como a questão básica é o esquema moraico e como ele é encontrado em todas as línguas, a título de ilustração do fenômeno, serão apresentados, a seguir, alguns fatos com comentários sucintos. Os dados referemse a um falante adulto do dialeto paulista, numa pronúncia formal.

Dada a dificuldade de encontrar trabalhos que analisem as moras das línguas, os exemplos abaixo podem dar uma ideia clara de como se faz uma análise desse tipo. Assim, os exemplos abaixo apresentam alguns enunciados com os valores duracionais das sílabas, medidos através do PRAAT e com as marcações moraicas das sílabas, anotadas com o uso de uma interpretação auditiva das durações relativas das sílabas. Mais adiante, são apresentados os espectrogramas de dois enunciados, com os respectivos comentários.

A notação das moras das sílabas, neste trabalho, recebeu os seguintes símbolos e valores correspondentes: = ultralonga; - longa; $\Lambda$ média / igual; $v$ breve; " ultrabreve.

(1) Heitor.

\begin{tabular}{|l|l|}
\hline$v$ & $=$ \\
\hline Hei- & -tor \\
\hline 0.162 & 0.450 \\
\hline
\end{tabular}

(2) Heitor dá dó!

\begin{tabular}{|l|l|l|l|}
\hline$\Lambda$ & $\Lambda$ & $\Lambda$ & $\Lambda$ \\
\hline Hei- & -tor & dá & dó \\
\hline 0.107 & 0.360 & 0.206 & 0.253 \\
\hline
\end{tabular}


(3) Cândido Heitor.

\begin{tabular}{|l|l|l|l|l|}
\hline- & $v$ & & $v$ & $=$ \\
\hline Can- & -di- & -do & Hei- & tor \\
\hline 0.190 & 0.146 & 0.103 & 0.130 & 0.438 \\
\hline
\end{tabular}

(4) Heitor dorme cedo.

\begin{tabular}{|l|l|l|l|l|l|}
\hline$v$ & $=$ & - & $v$ & $=$ & $v$ \\
\hline Hei- & -tor & dor- & -me & ce- & -do \\
\hline 0.135 & 0.341 & 0.278 & 0.147 & 0.316 & 0.201 \\
\hline
\end{tabular}

(5) Heitor estuda em Araraquara.

\begin{tabular}{|l|l|l|l|l|l|l|l|l|l|l|}
\hline$\ll$ & $=$ & $v$ & - & $«$ & $v$ & $\ll$ & $v$ & u & $=$ & $v$ \\
\hline Hei- & -tor & es- & -tu- & - da & Em & A- & -ra- & -ra- & -qua- & -ra \\
\hline 0.128 & 0.335 & 0.232 & 0.203 & 0.139 & 0.189 & 0.118 & 0.146 & 0.132 & 0.317 & 0.175 \\
\hline
\end{tabular}

(6) Heitor estuda na universidade de Araraquara.

\begin{tabular}{|l|l|l|l|l|l|l|l|l|}
\hline$«$ & $=$ & $v$ & - & $v$ & $v$ & $v$ & $v$ & $v$ \\
\hline Hei- & -tor & es- & -tu- & - da & na u- & -ni- & -ver- & -si- \\
\hline 0.148 & 0.291 & 0.208 & 0.141 & 0.155 & 0.184 & 0.125 & 0.120 & 0.164 \\
\hline
\end{tabular}

\begin{tabular}{|l|l|l|l|l|l|l|l|}
\hline- & $«$ & $v$ & $\ll$ & $v$ & $v$ & $=$ & " \\
\hline -da- & -de & de & A- & -ra- & -ra- & -qua- & -ra \\
\hline 0.166 & 0.136 & 0.134 & 0.063 & 0.146 & 0.096 & 0.305 & 0.166 \\
\hline
\end{tabular}

(7) Heitor não estuda na universidade de Araraquara.

\begin{tabular}{|l|l|l|l|l|l|l|l|l|l|}
\hline$v$ & $=$ & - & $v$ & - & " & $v$ & $v$ & $v$ & $v$ \\
\hline Hei- & -tor & não & es- & -tu- & - da & na u- & -ni- & -ver- & -si- \\
\hline 0.166 & 0.353 & 0.300 & 0.195 & 0.172 & 0.155 & 0.188 & 0.131 & 0.160 & 0.173 \\
\hline
\end{tabular}

\begin{tabular}{|l|l|l|l|l|l|l|l|}
\hline- & $v$ & " & & $v$ & $v$ & $=$ & " \\
\hline -da- & -de & de & A- & -ra- & -ra- & -qua- & -ra \\
\hline 0.222 & 0.126 & 0.131 & 0.066 & 0.152 & 0.130 & 0.330 & 0.167 \\
\hline
\end{tabular}


Valores duracionais (moras) para a palavra Heitor:

\begin{tabular}{|l|l|l|}
\hline Hei- & -tor & (enunciado completo) \\
\hline 0.162 & 0.450 & Heitor. \\
\hline 0.135 & 0.341 & Heitor dorme cedo. \\
\hline 0.128 & 0.335 & Heitor estuda em Araraquara. \\
\hline 0.148 & 0.291 & Heitor estuda na universidade de Araraquara. \\
\hline 0.166 & 0.353 & Heitor não estuda na universidade de Araraquara. \\
\hline 0.130 & 0.438 & Cândido Heitor. \\
\hline 0.107 & 0.360 & Heitor dá dó. \\
\hline
\end{tabular}

Valores duracionais (moras) para a palavra Araraquara:

\begin{tabular}{|l|l|l|l|l|l|}
\hline A- & -ra- & -ra- & -qua- & -ra & (enunciado completo) \\
\hline 0.118 & 0.146 & 0.132 & 0.317 & 0.175 & Heitor estuda em Araraquara. \\
\hline 0.063 & 0.146 & 0.096 & 0.305 & 0.166 & Heitor estuda na universidade de Araraquara. \\
\hline 0.066 & 0.152 & 0.130 & 0.350 & 0.167 & Heitor não estuda na universidade de Araraquara. \\
\hline
\end{tabular}

Nos exemplos apresentados acima, os enunciados aparecem cada vez mais longos, justamente para se avaliar até que ponto a análise auditiva segue de perto a análise acústica. A análise auditiva foi feita antes da análise acústica. Nos enunciados analisados, não houve alteração de nenhum padrão marcado auditivamente, mesmo quando a análise acústica da duração das sílabas apresentou valores que poderiam ser contraditórios, como um valor muito baixo para uma sílaba breve (e não ultrabreve) ou o contrário, um valor alto para o que foi interpretado como sílaba ultrabreve (e não breve). É claramente evidente que o ouvido trabalha com um processo de categorizaçáo diferente do modo como o PRAAT analisa a duração das sílabas. São duas coisas diferentes por natureza. Apesar das diferenças, os valores moraicos têm limites, e uma categoria de duração determinada não se mistura com outra. $\mathrm{O}$ mesmo efeito já não se pode dizer dos valores duracionais das mesmas sílabas, medidos através do PRAAT. Assim como na entoação, os fenômenos de downstep, downdrift, plateau, efeito de tessitura, afetando os valores de $\mathrm{H} \mathrm{e} \mathrm{L}$, medidos acusticamente, assim também acontece com a análise moraica das sílabas, medidas acusticamente. Na análise entoacional, a interpretação auditiva também segue categorias bem definidas, mas o mesmo efeito não se pode dizer das alturas melódicas, coletadas 
acusticamente. ${ }^{21}$ Em ambos os casos, como se trata da análise de uma língua que tem falantes e ouvintes, e não máquinas que conversam entre si, a interpretação auditiva deve orientar a interpretação acústica, e não vice-versa. Um foneticista bem treinado pode pegar os enunciados apresentados como exemplos, reproduzir o que foi dito, seguindo os padrões das moras e avaliar por si, como essas medidas existem na mente dos falantes, do mesmo modo como fazemos com as análises segmentais das vogais e das consoantes, e de seus respectivos formantes, ${ }^{22}$ ou com a análise dos padrōes entoacionais e suas variaçôes de $\mathrm{He}$ de L (LADEFOGED, 1973). Curiosamente, se alguém regravar os exemplos dados, atendo-se rigorosamente aos padrōes assinalados, o resultado acústico vai ser bem próximo dos apresentados acima. Esse processo permite que segmentos e unidades da fala possam ter o status fonológico de fonemas. É por isso que se pode fazer fonologia da entoação ou do ritmo. Essa correspondência é que faz com que falemos uma mesma língua, seguindo os mesmos padrōes sistemáticos. O sistema que está na mente do falante também está na mente do ouvinte.

A seguir, são apresentados os espectrogramas de dois enunciados, para ilustração das moras.

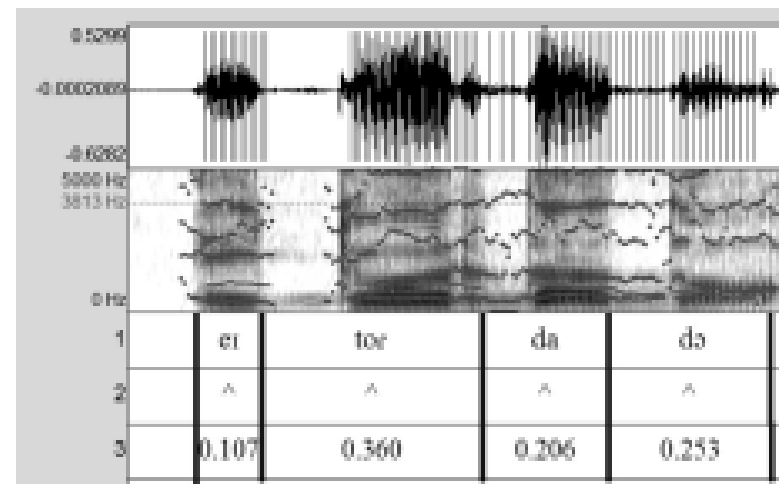

FIGURA 1 - Tela do PRAAT com os valores das sílabas e a marcação das moras para o enunciado Heitor dá dó. O enunciado foi percebido como tendo sílabas de igual duração. 

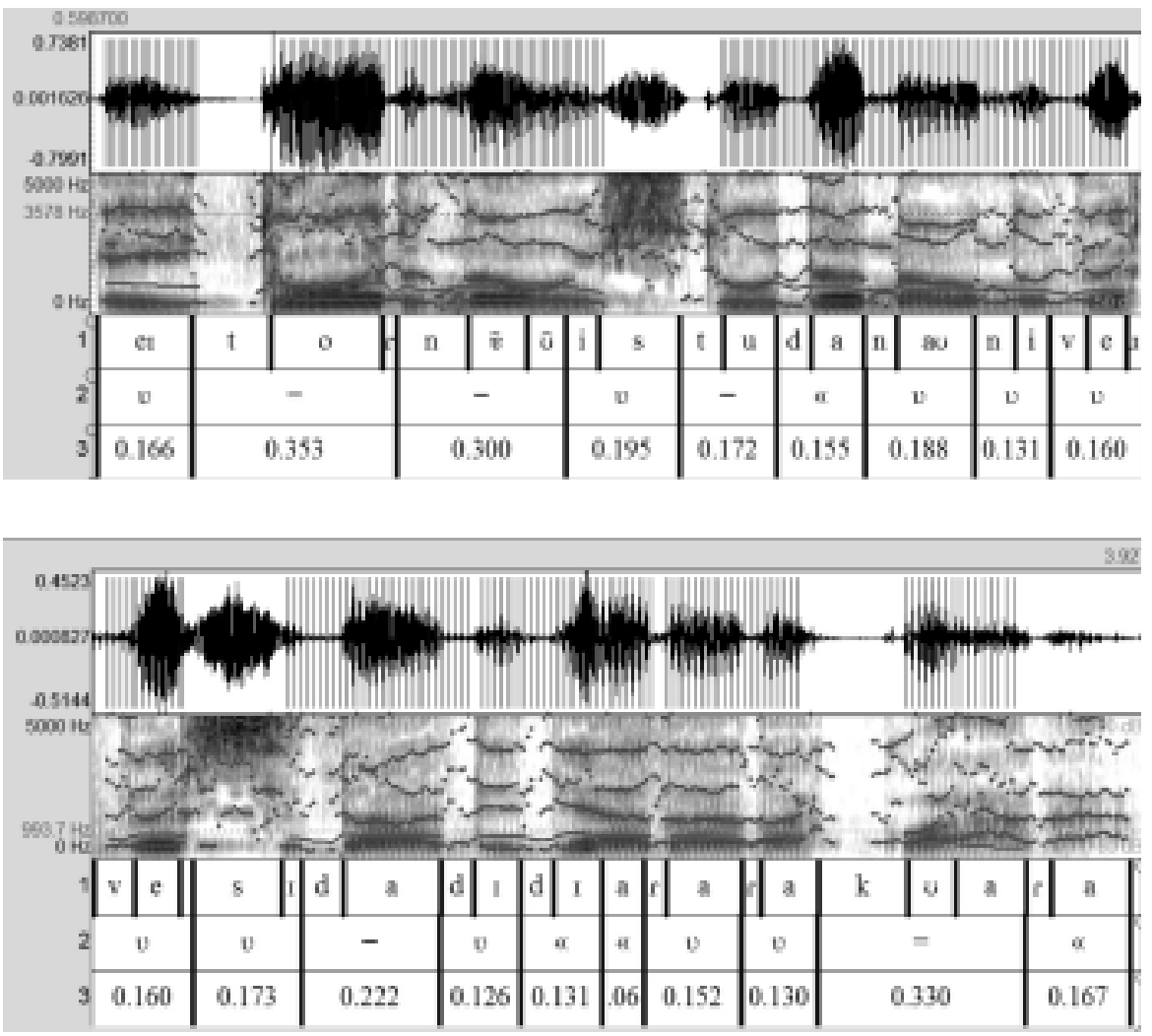

FIGURA 2 - Tela do PRAAT, mostrando os valores duracionais das sílabas e a marcação das moras, para o enunciado Heitor não estuda na universidade de Araraquara.

O enunciado da FIG. 1 foi escolhido porque ocorrem três sílabas tônicas contíguas. Enunciados construídos desse modo tendem a ter uma sequência de sílabas iguais. Ao analisar os valores acústicos, nota-se que a primeira sílaba se diferencia muito das demais, sendo, na verdade, uma sílaba breve. Nota-se também uma tendência do falante para enfraquecer a segunda tônica, fazendo dela uma sílaba menos longa do que a terceira sílaba, para evitar que a fala seja monótona. A alternância entre sílabas longas e breve é algo esperado, sobretudo, de uma língua de ritmo acentual (mas também de línguas nas quais a duração silábica é fonologicamente contrastiva, criando fonemas longos e breves). A sílaba tônica (-tor) da palavra Heitor tem uma duração mais longa do que a tônica final, 
na palavra dó, porque o foco foi deslocado da última tônica (lugar mais comum) para a primeira, que foi destacada desse modo, fazendo da palavra o tema ou elemento dado do processo comunicativo (HALLIDAY, 1976).

Na FIG. 2 (em duas partes na folha), temos um enunciado longo, com uma sequência longa de sílabas breves. Enunciados desse tipo apresentam dificuldades de fala e, comumente, apresentam processos fonológicos específicos em certos contextos. Em outra gravação do mesmo enunciado, o falante não disse o de na sequência universidade (de) Araraquara. O ditongo formado na juntura de palavras na universidade, apresenta uma qualidade vocálica baixa posterior em seu início e uma qualidade vocálica meio baixa posterior, levemente centralizada. Em um nível mais detalhado de transcrição fonética, temos aí o ditongo [???]. O abaixamento vocálico final é consequência do ritmo. Numa outra pesquisa, o falante foi solicitado a dizer frases cada vez maiores, usando palavras repetidas. Comparando-as, nota-se que a variação ocorre não apenas acusticamente mas também auditivamente. Além disso, como se observou anteriormente, a correlação entre moras e duraçóes apresentadas nos espectrogramas tem categorias definidas e limites de valores (CAGLIARI; CARVALHO; GEMENTI, 2012).

\section{Conclusão}

Com relação aos estudos da tipologia rítmica das línguas, as investigações acústicas ficaram devendo algumas explicações importantes, como o controle do andamento sobre o valor duracional exato das sílabas, em função de sua realidade linguística. Sem esse parâmetro, os valores atribuídos às sílabas podem variar incontroladamente, levando a resultados absurdos. Porém, não conheço nenhum trabalho acústico que tenha resolvido esse problema. A velocidade de fala (speech rate), obviamente, não é exatamente a medida do andamento. As análises acústicas apoiaram-se em uma noção de isocronia nunca definida em termos acústicos, mas apenas em termos perceptuais auditivos. A correlação entre uma coisa e outra não pode ser feita diretamente (CAGLIARI; CARVALHO; GEMENTI, 2012)

A isocronia é um modo de apontar para um tipo de regularidade, porque o ritmo é uma regularidade. Uma isocronia absoluta não ocorre na música instrumental nem na cantada. Uma orquestra ou coral são regidos pelo andamento, e não pela isocronia. A mesma coisa acontece com a fala. ${ }^{23}$ Ritmo 
está associado à noção de expectativa de repetição, que é um construto da mente, e não da realidade acústica. Não é difícil construir uma teoria fonológica da mente do falante. Certamente, essa teoria deve ter um correlato físico-acústico na fala, mas ainda não sabemos fazer essa relação.

Todas as línguas têm uma estrutura moraica (como definida neste trabalho), que atribui a cada sílaba um valor determinado pelo léxico da língua. Quando esses valores são mantidos inalterados no enunciado, tem-se uma língua de ritmo silábico. Quando a estrutura moraica sofre uma compactação ou dilatação para ajustar o ritmo com intervalos regulares entre as sílabas tônicas do enunciado, tem-se uma língua de ritmo acentual. Infelizmente, a linguística moderna criou uma categoria de mora que atropelou a velha noção de moras que vinha desde os estudos prosódicos greco-latinos. A palavra mora tornou-se ambígua e essa ambiguidade trouxe muita confusão.

Finalmente, o estudo do ritmo das línguas tem andado por caminhos estranhos porque as unidades básicas foram mal definidas, como a tonicidade lexical e textual, a isocronia absoluta, admitida por muitos, e a falsa caracterização da duração no léxico e nos enunciados, obtida por meio de análises acústicas equivocadas. Além disso, ficaram faltando estudos mais envolvidos com o processo cognitivo e fonológico dos sistemas das línguas.

\section{Notas}

${ }^{1}$ Isso levou alguns linguistas a acharem que sílaba é apenas uma unidade fonológica e não fonética. Foneticamente, se não há sílaba, não há moras, não há acento, não há ritmo. Essa abordagem leva facilmente à conclusão de que ritmo é uma realidade gerada por um modelo de fonologia prosódica. Consequentemente, para eles, não faz sentido discutir se as línguas são de ritmo acentual ou silábico. Esses pesquisadores nunca se referem ao processo aerodinâmico de produção da fala, mas apenas acústico. Porém, nem toda realidade fonética é produzida acusticamente.

${ }^{2}$ Jerônimo Soares Barbosa (1822) diz: "Quantidade é a medida da duração que damos à pronunciação de qualquer sílaba. Esta duração é toda relativa, bem como o é a das notas da música, em que uma não é mais longa senão comparada com outra que o é menos. Assim, pois, como na música as notas têm a mesma quantidade relativa nos alegros, que têm nos adágios, comparada entre si, dentro do mesmo ar de compasso, posto que uma nota da mesma espécie gaste mais tempo realmente no adágio, que no alegro: assim na pronunciação de uma Língua, as sílabas medem- 
se não pelo vagar ou pela velocidade acidental da mesma pronunciação, mas relativamente às proporções imutáveis que as fazem ou longas, ou breves. Dois homens, um dos quais é sumamente veloz no falar, e outro, por extremo vagaroso e compassado, não deixam por isso de observar a mesma quantidade, ainda que o primeiro pronuncie mais depressa uma longa que o outro uma breve. Ambos eles não deixam de fazer exatamente breves as que são breves e longas as que são longas, só com a diferença que um gasta duas, três e quatro vezes mais tempo que o outro para as articular. A medida por tanto da quantidade de cada sílaba é a proporção invariável que umas têm com outras: proporção incomensurável que nunca se pode determinar exatamente; porque em todas as Línguas e na Portuguesa também, há sílabas breves mais breves que outras; e longas mais longas umas que as outras; e isto consideradas, ou sós por ordem às vozes, ou também por ordem às consonâncias que se lhes ajuntam" (BARBOSA, 1822, p. 27-28).

${ }^{3}$ Como diz Abercrombie (1967, p. 89-110), para se estudar a dinâmica da fala, é preciso estudar a duração segmental, a acentuação, a velocidade de fala (tempo), o andamento, a concatenação (continuity), a tessitura, o registro, entoação (pitch fluctuation) e até a qualidade de voz. Como todos esses parâmetros se integram a cada momento, analisar a fala é um problema que requer muitos cuidados especiais. ${ }^{4}$ Para uma revisão de alguns conceitos sobre a estrutura rítmica da música, veja, por exemplo, COOPER, G.; MEYER, L. B. (1960); DRAKE, C.; PALMER, C. (1993).

${ }^{5}$ Os pesquisadores foneticistas precisam parar de usar o termo isocronia com um valor absoluto. Por outro lado, pode-se fazer estudos estatísticos com dados controlados auditivamente. Veja, por exemplo, o trabalho de LADEFOGED (1973), avaliando as vogais cardeais.

${ }^{6}$ NEBRIJA (1492) diz: "I no se espante ninguno por que dixe que la proxa tiene su medida, por que es cierto que la tiene i aun por aventura mas estrechas que la del verso... mas delos numeros i medidas dela proxa diremos en otro lugar" (Gramática Castelhana,1492, II, 5). Ele também observa: "Mas el castellano no puede sentir esta diferencia: ni los que componen verso puden distinguir las sílabas luengas de las breves" (Cap. I, Livro II). Veja também BALAGUER (1954).

${ }^{7}$ Aspectos aerodinâmicos da fala podem ser revistos em ABERCROMBIE (1967), LADEFOGED (1967), CATFORD (1977); CAGLIARI (2007).

${ }^{8}$ Um bom teste para saber se uma língua é de ritmo acentual ou não é contar, por exemplo, 20, 21, 22, 23, 24, 25, 26, 27, 28, 29, 30. Se o falante marcar uma sílaba tônica para cada número de modo compassado, a língua é de ritmo acentual. Caso contrário, a língua é de ritmo silábico. 
${ }^{9}$ Alguns conceitos importantes sobre duração silábica podem ser vistos em ABERCROMBIE (1965) e CAGLIARI (2007, p. 134-141). Veja também comentários a esse respeito, apresentados anteriormente, comentando a citação de RAVIZZA (1940). ${ }^{10}$ Com relação a noções básicas da linguística cognitiva, veja FELTES (2007), ABREU (2010), FERRARI (2011).

${ }^{11}$ Veja o site <http://www.sljfaq.org/afaq/mora.html> para a diferença entre sílaba e mora em japonês. Ladefoged (1975, p. 223-234) mostra como as moras funcionam em japonês. Trata-se de uma língua com sistema moraico do tipo greco-latino. $\mathrm{O}$ que diferencia o japonês de outras línguas semelhantes são as regras de atribuição de moras aos segmentos. Por exemplo, na palavra [nippo?] ocorrem duas sílabas mas as moras são distribuídas sobre quatro elementos: [ni p po ?], de acordo com a tradição poética da língua. Lembrar que a escrita japonesa é silábica. Veja também LAVER (1994, p. 527-533).

${ }^{12}$ A afirmação de Lloyd James, aproveitada por Abercrombie (1967, p. 171), é muito infeliz, quando diz que o japonês é uma língua do tipo machine-gun, porque é uma caricatura da fala da língua, revelando um certo preconceito. Diante de uma língua desconhecida, uma pessoa é facilmente levada a fazer afirmaçōes erradas e, não raramente, preconceituosas. Por exemplo, é comum afirmaçôes de que os falantes de uma língua desconhecida falam rápido demais, de modo um tanto atropelado. Os próprios falantes não acham isso, eles falam tranquilamente. Pike, que cunhou os rótulos de língua de ritmo acentual ou silábico, pegou a ideia de Daniel Jones: "For this basic principle of the timing of rhythm units and for similar illustrations I am indebted to D. Jones, Outline of English Phonetics, $\$ \$ 886-890 ”(P I K E, 1945$, p. 186).

${ }^{13}$ Se os foneticistas que classificaram o japonês como língua de ritmo moraico pela semelhança com o grego e o latim (número de moras e não número de sílabas na poesia - e na prosa) tivessem lido a Gramática Filosófica de Jerônimo Soares Barbosa (1822, p. 27-44) e visto a análise que ele faz do português, teriam incluído o português na categoria das línguas (raras!) do tipo moraico (não acentual, nem silábico). Entretanto, nada disso faz sentido: não existe um tipo especial de língua de ritmo moraico, porque as línguas assim descritas são tipicamente línguas de ritmo silábico. (veja, exemplos do japonês em <http://www.sljfaq.org/afaq/mora.html>, acessado em: 28 jun. 2012 - e em outros sites).

${ }^{14}$ Portanto, a crítica que Barbosa $(2000,2004)$ faz a Abercrombie é injusta. Obviamente, Abercrombie, um inglês que morava em Edimburgo, sabia muito bem essas diferenças. $\mathrm{O}$ inglês escocês é tipicamente uma língua de ritmo silábico. 
${ }^{15} \mathrm{Na}$ literatura especializada, há muitos trabalhos que se referem a problemas de variação de ritmo nas línguas, a julgar de acordo com metodologias específicas de cada autor, comentando outros autores ou definindo posiçôes próprias, fruto de como conduziram suas pesquisas. Não é o caso de fazer uma revisão geral da literatura a esse respeito. Porém, para ilustrar o problema, podem ser vistos os seguintes trabalhos: ABAURRE, M. Bernadete; GALVES, Charlotte (1998); BARBOSA, Plínio A. (2000); BERTINETTO, P. (1989); CAGLIARI, L. C.; ABAURRE, M. Bernadete (1986); CARVALHO (1988); DAUER, R. M. (1983); DELLATRE, P. (1966); FROTA, Sónia; VIGÁRIO, Marina (1999); MAJOR, Roy, C. (1981, 1985); O’DELL, M.; NIEMINEN, T. (1999); POMPINO-MARSCHALL, B. (1989); ROACH, P. (1982).

${ }^{16}$ Mais recentemente, apareceram vários trabalhos que foram investigar se bebês (ou mesmo crianças ainda no útero das mães) tinham alguma reação ao ritmo linguístico de diferentes línguas. A questão metodológica é problemática, o que dificulta a aceitação das conclusōes. Entre outros, veja: NAZZI, T.; BERTONCINI, J.; MEHLER, J. (1998); RAMUS, Franck; NESPOR, Marina; MEHLER, Jacques (2000).

${ }^{17}$ Cf. o Dies irae da missa dos mortos e a poesia medieval das línguas românicas.

Dies irae, dies illa

Solvet saeclum in favilla:

Teste David cum Sibylla.

Quantus tremor est futurus

Quando judex est venturus,

Cuncta stricte discussurus! (e o poema continua)

${ }^{18} \mathrm{Na}$ arte poética latina, as poucas palavras que tinham três ou quatro sílabas breves seguidas eram evitadas.

${ }^{19}$ Neste trabalho, a noção de foco é a adotada por Halliday (1976) e Cagliari (2007). Nessa abordagem o foco divide a informação do enunciado em categorias semânticas e sintáticas, como dado/novo, tema/rema, componente pretônico e tônico, na descrição entoacional.

${ }^{20}$ Infelizmente, a nossa escrita pode interferir na interpretação da oralidade pelo modo como separamos as palavras na escrita ortográfica.

${ }^{21}$ Os estudos sobre entoação costumam estar intimamente ligados aos estudos concomitantes do ritmo. Um exemplo bem notável são os trabalhos de Halliday (1967, 1970, 1973), Cagliari (1982, 2007, p. 131-191), Halliday; Greaves (2008). Usando uma metodologia diferente, Pierrehumbert (1980) também integra a descrição da entoação com uma descrição do ritmo, por meio da grade métrica fonológica. 
${ }^{22}$ Houve muita queixa de pesquisadores que se insurgiram contra a classificação rítmica das línguas, mas, curiosamente, é muito raro encontrar alguém se queixando de como a análise acústica interpreta as vogais. A variação nas frequências dos formantes é tão grande quanto a variação da suposta isocronia. Sem uma análise auditiva prévia, feita por foneticista bem treinado, a análise das vogais acusticamente é um caos.

${ }^{23}$ Em reza coletiva - por exemplo, do rosário - todos rezam em uníssono, sem perder o ritmo da língua. Antigamente, rezava-se em latim, com uma prosódia típica do português, com ritmo acentual, e não silábico, porque ninguém sabia como eram as moras do latim que diziam.

\section{Referências}

ABAURRE, M. B.; GALVES, C. As diferenças rítmicas entre o português europeu e o português brasileiro: uma abordagem otimalista e minimalista. DELTA, São Paulo: EDUC, v. 14, n, 2, p. 377-403, 1998.

ABERCROMBIE, D. A phonetician's view of verse structure. In: Studies in phonetics and linguistics. Oxford: Oxford University Press, 1965. p. 16-25.

ABERCROMBIE, D. Syllable quantity and enclitics in English. In: Studies in phonetics and linguistics. Oxford: Oxford University Press, 1965a. p. 26-34.

ABERCROMBIE, D. Elements of general phonetics. Edinburgh: Edinburgh University Press, 1967.

ABREU, A. Linguística cognitiva: uma visão geral e aplicada. São Paulo: Ateliê Editorial, 2010.

ALLEN, W. S. Accent and rhythm: prosodic features of Latin and Greek: a study in theory and reconstruction. Cambridge: Cambridge University Press, 1973.

ALLEN, G. D. Speech rhythm: its relation to performance universals and articulatory timing. Journal of phonetics, v. 3, p. 75-86, 1975.

ANDRADE, E. d'; LAKS, B. Na crista da onda: o acento de palavra em Português. Lisboa: Universidade de Lisboa, CNRS, 1991.

BALAGUER, J. Apuntos para una historia prosodica de la metrica castellana. Madrid: Consejo Superior de Investigaciones Cientificas - Anejos de revista de literatura, n. 13, Instituto Miguel Cervantes de Filologia Hispanica, 1954.

BARBOSA, J. S. Gramatica philosophica da lingua portuguesa. Lisboa: Typographia da Academia das Sciencias, 1822. 
BARBOSA, P. A. Syllable-timing in Brazilian Portuguese: uma crítica a Roy Major (Tempo-silábico em Português do Brasil: a critic to Roy Major). DELTA, v. 16, n. 2, p. 369-402, 2000.

BARBOSA, P. A. Elementos para uma tipologia do ritmo (linguístico) da fala. Cognito Cadernos românicos em ciências cognitivas, Grenoble, França, v. 2, n. 1, p. 31-58, 2004.

BARBOSA, P. A. Incursões em torno do ritmo da fala. Campinas: Pontes Editores. 2006.

BARBOSA, P. A.; Silva, W. A. New methodology for comparing speech rhythm structure between utterances: beyond typological approaches. In: CASELI, H.; VILLAVICENCIO, A.; TEIXEIRA, A.; Perdigão, F. (Ed.). Computational processing of the Portuguese Language, Berlin: Springer, 2012. v. 7243, p. 329-337.

BERTINETTO, P. Reflections on the dichotomy stress vs. syllable-timing. Revue de phonétique appliquée, p. 91-93; 99-130, 1989.

BOERSMA, Paul; WEENINK, David. PRAAT. Disponível em: <http:// www.fon.hum.uva.nl/praat>. Acesso em: 29 jun. 2012.

BULLOCK, Ben. What is the difference between a mora and a syllable: In: scil.lang.japan FAQ 7.6. Disponível em: <http://www.sljfaq.org/afaq/mora.html>. Acesso em: 29 jun. 2012.

CAGLIARI, L. C. Investigando o ritmo da fala. In: Anais do Vencontro nacional de linguistica, Rio de Janeiro: PUCRJ, p. 290-304, nov/80, 1980.

CAGLIARI, L. C. A entoação e o ritmo do português brasileiro: algumas análises espectrográficas. Revista IBM, Ano IV, n. 13, p. 24-33, set. 1982.

CAGLIARI, L. C. Análise fonética do ritmo em poesia. In: EPA: Estudos portugueses e africanos, 3, p. 67-96, UNICAMP - IEL, Departamento de Teoria Literária, 1984.

CAGLIARI, L. C. O ritmo do Português na interpretação de Jerônimo Soares Barbosa. In: Anais do I Encontro Nacional de Fonética e Fonologia: UFSC Working papers in linguistics. ANGENOT, J. P. et al. (Ed.). 5, v. 1, p. 27-38, Florianópolis, 1985.

CAGLIARI, L. C. Da Importância da prosódia na descrição de fatos gramaticais. In: ILARI, R. (Org.). Gramática do português falado: níveis de análise linguística, Campinas: Editora da Unicamp, 1992. v. 2, p. 39-64.

CAGLIARI, L. C. Elementos de fonética do Português Brasileiro. São Paulo: Editora Paulistana, 2007. 
CAGLIARI, L. C. Prosódia: ontem e hoje. In: FONSECA-SILVA, M. C.; PACHECO, V.; LESSA-DE-OLIVEIRA, A. S. C. (Org.). Em torno da lingua(gem): questões e análises. Vitória da Conquista: Edições UESB, 2007a. p. 15-40.

CAGLIARI, L. C. Aspectos teóricos da ortografia. In: SILVA, M. (Org.). Ortografia da língua portuguesa: história, discurso e representações. São Paulo: Editora Contexto, 2009. p.17-52.

CAGLIARI, L.; ABAURRE, M. B. Elementos para uma investigação instrumental das relaçōes entre padrões rítmicos e processos fonológicos no Português brasileiro. Cadernos de estudos linguísticos, Campinas: UNICAMP-IEL-DL, v. 10, p. 39-57, 1986.

CAGLIARI, L. C.; MASSINI-CAGLIARI, G. Quantidade e duração silábicas em Português do Brasil. DELTA, São Paulo: PUC-SP, v. 14. n. Especial, p. 47-59, 1998.

CAGLIARI, L. C.; CARVALHO, M.; GEMENTI, M. M. Revisiting the acoustic and auditory approach to speech analysis. Text presented at GSCP, Belo Horizonte: UFMG, FALE, 2012. ms.

CÂMARA JR, J. M. História e estrutura da língua portuguesa. Rio de Janeiro: Padrão, 1985.

CARVALHO, J. B. Réduction vocalique, quantité et accentuation: pour une explication structurale de la divergence entre portugais lusitanien et portugais brésilien. Boletim de filologia, Lisboa, v. 32, p. 5-26, 1988.

CASTILHO, A. F. Tratado de metrificação portuguesa. Lisboa: Empreza da História de Portugal, Sociedade Editora, 1850, ed. de 1908. 2 v.

CATFORD, J. C. Fundamental problems in phonetics. Edinburgh: Edinburgh University Press, 1977.

CAVALCANTI PROENÇA, M. Ritmo e poesia. Rio de Janeiro: Org. Simōes, 1955. CLASSE, A. The rhythm of English prose. Oxford: Backwell, 1939.

COOPER, G.; MEYER, L. B. The rhythmic structure of music. Chicago: University of Chicago Press, 1960.

CRYSTAL, D. Prosodic systems and intonation in English. London: Cambridge University Press, 1969.

CRYSTAL, D. The English tone of voice: essays in intonation, prosody and paralanguage. London: Edward Arnold, 1975.

DAUER, R. M. Stress-timing and syllable-timing reanalyzed. Journal of Phonetics, v. 11, p. 51-62, 1983. 
DELLATRE, P. A comparison of syllable length conditioning among languages. IRAL, v. 4, p. 183-196, 1966.

DRAKE, C.; PALMER, C. Accent structures in music performance. Music perception, v. 10, n. 3, p. 343-378, 1993.

FELTES, H. P. M. Semântica cognitiva: ilhas, pontes e teias. Porto Alegre: EDIPUCSRS, 2007.

FERRARI, L. Introdução à linguística cognitiva. São Paulo: Editora Contexto, 2011. FROTA, S.; VIGÁRIO, M. Aspectos de prosódia comparada: ritmo e entoação no PE e no PB. In: Actas do XV Encontro Nacional da APL. Faro: APL, v. I. p. 533-555, 1999.

HALLIDAY, M.A.K. Intonation and grammar in British English. Janua linguarum, series practica, 48. The Hague: Mouton, 1967.

HALLIDAY, M. A. K. A course in spoken English: intonation. London: Oxford University Press, 1970.

HALLIDAY, M. A. K. The tones of English. In: JONES, W. E.; LAVER, J. Phonetics in linguistics (Ed.). London: Longman, 1973. p. 103-126.

HALLIDAY, M. A. K. Estrutura e função da linguagem. In: LYONS, J. (Org.). Novos horizontes em linguística. São Paulo: Cultrix / EDUSP, 1976. p. 134-160.

HALLIDAY, M. A. K.; GREAVES, W. S. Intonation in the grammar of English. London: Equinox, 2008.

JAMES, L. A. Speech signals in telephony. London, 1940.

JONES, D. An outline of English phonetics. Cambridge: Cambridge University Press, 1960, 1st ed. 1917.

LADEFOGED, P. Three areas of experimental phonetics. London: Oxford University Press, 1967.

LADEFOGED, P. The value of phonetic statements. In: JONES, W. E. and LAVER, J. (Ed.). Phonetics in linguistics: a book of readings. London: Longman, 1973. p. 218-228.

LADEFOGED, P. A course in phonetics. New York: Harcourt Brace Jovanovich, 1975.

LAVER, J.. Principles of phonetics. Cambridge: Cambridge University Press, 1994. LEHISTE, I. Suprasegmentals. Cambridge: The MIT Press, 1970.

MAJOR, R. C. Stress-timing in Brazilian Portuguese. Journal of phonetics, v. 9, p. 343-351, 1981. 
MAJOR, R. C. Stress and rhythm in Brazilian Portuguese. Language, v. 61, n. 2, p. 259-282, 1985.

MASSINI-CAGLIARI, G. Acento e ritmo. São Paulo: Ed. Contexto, 1994.

MASSINI-CAGLIARI, G.; CAGLIARI, L. C. Fonética. In: MUSSALIM, F.; BENTES, A. C. (Org.). Introdução à linguística: domínios e fronteiras. São Paulo: Contexto, 2000. p.105-146.

NAZZI, T.; BERTONCINI, J.; MEHLER, J. Language discrimination by newborns: towards an understanding of the role of rhythm. Journal of experimental psychology: human perception and performance, v. 24, n. 3, p. 756-766, 1998.

NEBRIJA, A. Gramática castelhana. 1492.

NESPOR, M.; VOGEL, I. Prosodic phonology. Dordrecht: Foris. 1986.

O'CONNOR, J. D. The perception of time intervals. In: Progress report 2. London: University College, Phonetic Laboratory, 1965. p. 11-15.

O'DELL, M.; NIEMINEN, T. Coupled oscillator model of speech rhythm. In: Proceedings of the XIVth international congress of phonetic sciences, v. 2, p. 10751078, 1999.

PATEL, A. D.; DANIELE, J. R. An empirical comparison of rhythm in language and music. Cognition, v. 87, B35-B45, 2003.

PIERREHUMBERT, J. B. The phonetics and phonology of English intonation. Ph.D. Thesis. Cambridge Massachusset: M.I.T, 1980.

PIKE, Kenneth Lee. The intonation of American English. Ann Arbor: The University of Michigan Press, 1945.

POMPINO-MARSCHALL, B. On the psychoacoustic nature of the p-center phenomenon. Journal of phonetics, v. 17, p. 175-192, 1989.

PORT, R. F., DALBY, J.; O’DELL, M. Evidence for mora-timing in Japanese. Journal of the acoustical society of America, v. 81, n. 5, p. 1574-1585, 1987.

RAMUS, Franck; NESPOR, Marina; MEHLER, Jacques. Correlates of linguistic rhythm in the speech signal. Cognition, v. 73, n. 3, p. 265-292, 2000.

RAVIZZA, J. Gramática latina. 9. ed. Niterói: Escolas profissionais salesianas, 1940.

REIS, C. A. C. Linteraction entre l'accent, l'intonation et le rythme en portugais brésilien. Thèse de doctorat. Aix-en-Provence: Université de Provence, Institut de Phonétique, 1995. 
ROACH, P. On the distinction between stress-timed and syllable-timed languages. In: CRYSTAL, D. (Ed.). Linguistic controversies. London: Edward Arnold, 1982.

SELKIRK, E. Phonology and syntax: the relation between sound and structure. Cambridge Massachusset: The M.I.T. Press, 1984.

SHEN, Y.; PETERSON, G. G. Isochronism in English. In: Occasional papers: studies in linguistics 9, University of Buffalo, 1962. p. 1-36.

STETSON, R. H. Motor Phonetics. Archives néerlandaises de phonétiques expérimentale. Amsterdam: North-Holland, 1951, 1st ed. 1928. v. III.

ULDALL, E. T. Isochronous stress in R.P. In: HAMMERICH, L. L.; JAKOBSON, R; ZWIRNER, E. (Ed.). Form and substance: phonetic and linguistic papers presented to Eli Fischer-Jorgensen. Akademisk Forlag, 1971. p. 205-210.

ULDALL, E. T. Relative durations of syllables in two-syllable rhythmic feet in R.P. in connected speech. In: Working in progress 5. Edinburgh: University of Edinburgh, Linguistic Department 1972. p. 110-111.

WARNER, N.; ARAI, T. The role of the mora in the timing of spontaneous Japanese speech. Journal of the acoustical society of America, v. 109, n. 3, p. 1144-1156, 2001. WENK, B.; WIOLLAND F. Is French really syllable-timed? Journal of phonetics, v. 10, p. 193-216, 1982.

WENK, B. J. Just in time: on speech rhythms in music. Linguistics, v. 25, p. 969981, 1987. 